\title{
Ecological Initiatives of the Global Catholic Climate Movement
}

\author{
Cecilia Dall'Oglio \\ Global Catholic Climate Movement \\ Al. Wojska Polskiego 27/11, 01-515 Warsaw, Poland \\ cecilia@catholicclimatemovement.global
}

\section{Summary}

This paper presents the structure and main aims of Global Catholic Climate Movement (GCCM): an international organization serving Catholics all over the world to promote ecological values. It points to a close connection between teaching of the Catholic Church and care about the creation. The efforts to prevent effects of climate changes are indicated as an important mission for believers, in accordance with Pope Francis' encyclical Laudato si'. There are three major dimensions describing how to bring Pope's teaching to life: spiritual dimension, lifestyle dimension and public policy dimension. In this article one can find many examples of good practices, which have been in the process of being realized since the GCCM was set up in 2015. The main content is followed by the detailed calendar, which shows the crucial achievements of GCCM.

\section{Keywords}

ecological crisis, Christianity, Global Catholic Climate Movement

The Global Catholic Climate Movement (GCCM) serves the Catholic family worldwide to turn Pope Francis' encyclical Laudato $s i$ into action for climate justice, by undergoing our own ecological conversion, transforming our lifestyles and calling for bold public policies together with the wider climate movement.

Founded in January 2015, GCCM is a coalition of more than 900 Catholic member organizations in all continents with a constituency of nearly one million Catholic individuals, guided by the international Steering Committee and a secretariat based in Rome. GCCM diverse membership reflects the diversity of our Catholic family: Caritas agencies, religious orders, lay movements, youth groups, diocesan organizations and Catholic-inspired NGOs are members of GCCM.

GCCM supports the Catholic Church to bring Laudato si' to life in the following 3 dimensions (which are all equally important to tackle this complex climate crisis):

1. SPIRITUAL DIMENSION: promotes Laudato si' and encourages local communities to undergo the 'ecological conversion' needed to overcome consumerism and heal people's relationship with creation and the poor; the Season of Creation is the flagship project.

2. LIFESTYLE DIMENSION: encourages lifestyle changes through the Eco-Parish program to reduce the carbon footprint from Catholic parishes 
worldwide and the Divest-Reinvest program to shift Catholic financial assets from dirty fossil fuels to clean renewable energy.

3. PUBLIC POLICY DIMENSION: raises the voice of Catholics in the public sphere to call for bold climate policies, by mobilizing in the streets, supporting advocacy efforts in the halls of power and amplifying the Laudato si' message in the media.

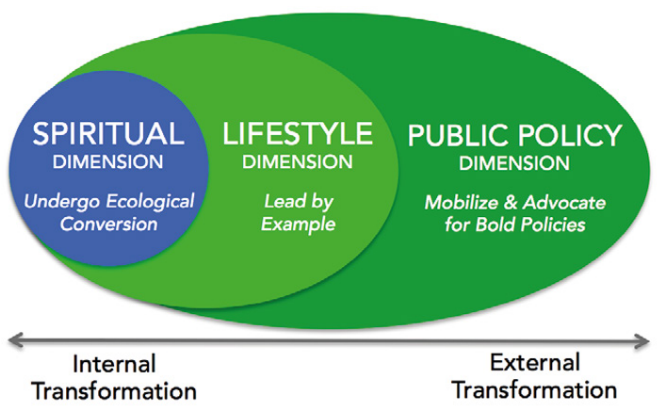

GCCM:

- $\quad$ promotes key global moments for its network and the Catholic family to take action together, maximizing the Church's collective impact;

- empowers the Catholic grassroots through the Laudato si' Animators program and decentralized tools and campaigns;

- is a sharing platform for Catholic organizations and individuals to share information and resources across the globe.

\section{Mission and goals}

Inspired by Pope Francis' encyclical Laudato si', GCCM's mission is to motivate the worldwide Catholic community to actively care for our common home and advance climate justice. GCCM's vision is of the Catholic community actively respecting life in all its forms so that all God's creatures flourish on Earth. Its vision includes a stable climate, where God's gift of creation is valued and shared equitably for the good of all, especially the poor and future generations. By partnering closely with the Vatican, the GCCM has three bold strategic goals: 1) instill deep eco-values in the $\mathbf{1 . 2}$ billion Catholic faithful and motivate a more passionate concern for nature, permeating society's cultural norms; 2) support the Church to shrink its huge carbon footprint; and 3) mobilize the Church to raise a loud and prophetic voice to reframe the climate debate in moral terms while calling for bold climate policies and 100\% renewable energy.

\section{Why the Catholic Church: the perfect storm of opportunity}

The Catholic Church has huge potential to accelerate global climate action because of the historic combination of a powerful set of conditions:

- The perfect leader: Pope Francis probably is the most admired and well respected leader on the planet, inspiring Catholics and non-Catholics alike to take climate action.

- A gigantic constituency: 1.2 billion Catholics have the potential to influence governments across continents while undergoing lifestyle changes at scale.

- Millennia-old territorial network: a well defined structure enables easy networking to reach 220,00o parishes in all 196 countries, plus thousands of religious orders, lay movements and other institutions.

- The perfect resource for climate campaigning: the Laudato si' encyclical made climate change a top priority for Catholics, and its strong moral message has huge potential to motivate climate action.

But these conditions are not sufficient. The Catholic Church has a strong institutional inertia that requires a new organization to truly tackle the opportunity and drive transformative action. That's where GCCM comes in. 


\section{Why GCCM: an innovative organization to mobilize the catholic church}

GCCM is the specialized and agile organization that was needed to lead transformative action in the Catholic Church. Founded in January 2015, GCCM mobilized nearly one million Catholics ahead of the Paris Climate Summit and became the go-to organization for Catholics interested in climate change (see highlights from 2015 and 2016). The key attributes of GCCM are-Global nature: GCCM is a global response to a global challenge, with more than 800 members; organizations in more than 80 countries and thousands of individual members in more than 140 countries:

- Vatican partnership: GCCM was blessed to count Pope Francis' support since the early days of the movement (see papal message), and continues to work closely with the Vatican.

- Grassroots focus, grasstops collaboration: GCCM's priority is to mobilize the Catholic grassroots, while collaborating as much as possible with the Church's hierarchy and being at its service.

- Network of organizations: GCCM intends to be a valuable resource for its member organizations to fulfill their charisms and missions, while mobilizing together in order to maximize impact.

- Community of practice: GCCM is a space for dialogue and learning between Catholic organizations and individuals to generate transformative action in this challenging issue.

- Nimble leadership: GCCM's leadership structures (i.e. the Board of Directors and Steering Committee) are fresh and nimble, allowing it to run innovative campaigns in an agile way.

- Digital-first campaigns: GCCM's 21st century mindset means that digital technology is at the core of its campaigns and programs, allowing it to scale quickly and operate smoothly across the globe.

\section{How does GCCM pursue its programs}

GCCM has programs in four areas, the first three match the strategic goals above and a fourth one that is cross-cutting:

1. ECO-CONVERSION PROGRAMS:

GCCM spearheads awareness-raising projects and eco-spirituality initiatives to help enshrine creation care as a Catholic priority:

- $\quad$ Spearhead large awareness-raising projects, such as "Large Church Event" interventions (WYD \& WMF) and the Laudato si' Movie.

- Enshrine the Season of Creation as a key moment in the Catholic calendar through large scale grassroots participation \& meaningful grasstops engagement (the ultimate goal is a liturgical reform).

- Nurturing our base with eco-spirituality initiatives as Laudato si' Retreats, the Laudato si' Circuit in Assisi \& liturgical season eco-resources.

2. FOOTPRINT PROGRAMS:

GCCM supports the Catholic Church to shrink its carbon footprint and lead by example, by:

- Recruiting Catholic facilities for the Sustainability program, with the emissions reductions targets to be confirmed,

- Assisting our members with sustainable lifestyles resources through ongoing online engagement.

3. ADVOCACY PROGRAMS:

GCCM raises a loud and prophetic Catholic voice for climate justice at all levels:

- The international level: Raise a strong Catholic voice in the international debate by delivering strategic communications for political events, supporting the Vatican to be more vocal, and targeting the fossil fuel industry through the divestment campaign.

- The national level: Support the Church in priority regions through in-country 
projects to elevate a stronger Catholic voice to pressure their governments to adopt stronger climate plans.

- The local level: Motivate our base to engage in decentralized grassroots advocacy and larger climate mobilizations together with the larger environmental movement.

4. M O VE M EN T - B U I L D I N G PROGRAMS:

Lastly, all the programming above is nurtured by programs to "build our muscle" and develop relationships that are needed to meaningfully activate the Church at all levels.

- Grasstops engagement to support and activate the Vatican and key bishops (relying on national partners whenever possible).

- The Member Organizations program to connect, support and activate the large global network of Catholic organizations.

- The Grassroots engagement journey, starting with online engagement and followed by the LS Animators program (and subsequent organizing through Circles and Chapters).

TARGET AUDIENCE: THE CATHOLIC COMMUNITY

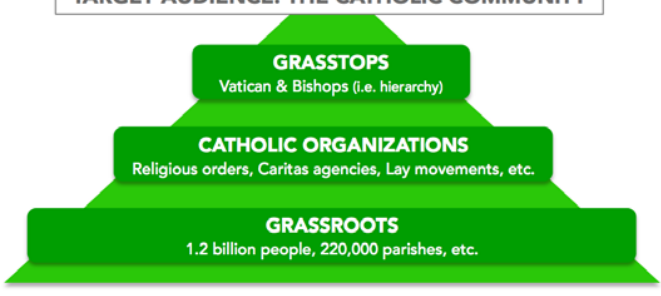

\section{The calendar of events}

\section{5}

1.Catholic Climate Petition was signed by 900,000 Catholics

In late November 2015, world leaders met in the U.N. Climate Summit at Paris with the goal of signing a treaty to tackle climate change. GCCM prepared a document called the Catholic Climate Petition. Through this petition, they urged their political leaders to commit to ambitious climate action and solve this urgent crisis. The Petition signatures were delivered to world leaders at the summit, together with the petitions of other interfaith and secular organizations. Ultimately, it aims to raise a strong Catholic voice supporting Pope Francis' words: “On climate change, there is a clear, definitive and ineluctable ethical imperative to act." Pope Francis endorsed the petition on May 2015 when he met with members of the Global Catholic Climate Movement in the Vatican. Cardinal Turkson, President of the Pontifical Council of Justice and Peace, endorsed the petition in Bolivia in July. Cardinal Tagle, President of Caritas Internationalis, recently signed the petition as part of a country-wide launch to gather 10 million signatures in the Philippines.

\section{Facts about climate change}

Climate change refers to changes in the global climate beyond those which we would expect to see due to natural climate variations. It is caused by carbon and other trace greenhouse gas (GHG) emissions. The United Nations Framework Convention on Climate Change (UNFCCC) defines climate change as a "change of climate which is attributed directly or indirectly to human activity that alters the composition of the global atmosphere and which is in addition to natural climate variability observed over comparable time periods." (Web-01) The level of agreement by informed scientists is exceedingly high. More than $99.9 \%$ of scientists published since 2013 agree that human activity is causing climate change (Web-02). There is a consensus among scientists that the climate is being changed by human activity, in the same way as there is consensus on the links between smoking and lung cancer.

\section{Why it is important}

The impacts of climate disruption are here and now, evident in extreme weather events such as floods, extreme storms, heat waves, 
and droughts. These impacts are projected to get a lot worse for everyone, especially those who are the most vulnerable, not least the poor, the unborn and future generations. As Catholics and Christians, we are called to care for our brothers and sisters and all of creation. Popes and Catholic Social Teaching are clear on our obligation to name systemic problems and damage such as climate change and address systemic injustice when it is needed. Bishops from all continents and now the Pope have issued letters and signed onto statements calling for limiting global warming to 1.5 degrees Celsius above pre-industrial levels. In the past year, scientists have said limiting increases to 2 degrees Celsius is "utterly inadequate" for protecting those at most risk, given the already observed impacts on ecosystems, food, livelihoods, and sustainable development. Further, the World Health Organization stressed that there is no "safe" level of warming and that current impacts and risks from climate change are already reaching unacceptable levels, with significant and inequitable health impacts on breathing, clean water, heat, flooding, and displacement (Web-03). Our leaders will not act unless we send a clear signal that we want immediate action on climate change to safeguard our common home and the future of our children. At the same time, the Pope has stated the need for "ecological conversion" by all, and a total structural change. People will be converted one at a time, through personal testimony and witness. It is all of our responsibility. In Laudato si' the Holy Father says we must get off fossil fuels "without delay." Burning large amounts of fossil fuels - coal, oil, natural gas - is the biggest cause of global warming. Each of us is responsible for helping to bring the call for "ecological conversion" to our families, parishes, communities, and societies. Talk with your priest, your parish, friends and family about climate change. Encourage them to pray with you, to sign the petition, and think together about ways to bring about the systemic change the Pope calls for.

2. The highest political authorities of $\mathrm{COP}_{21}$ heard Catholics' demand

GCCM delivered the 900,00o signatures to the highest political authorities of the historic Paris Climate Summit (COP21), together with an interfaith climate coalition (collectively we delivered 1.8 million signatures). Among them are: François Hollande, the French president who hosted $\mathrm{COP}_{21}$, Christiana Figueres, the U.N. climate chief in charge of the whole climate negotiations process, and also GCCM was represented on stage by Cardinal Hummes, who said "Formed only ten months ago, the GCCM has become a steadfast, faithful, and growing voice for climate justice."

The 1.5 degrees Celsius target in the Paris Agreement was a huge diplomatic victory as it dramatically raised the level of ambition, and GCCM's movement played a key role in advancing this cause as the Catholic Climate Petition was the only petition explicitly calling for this goal. The Philippine delegation at $\mathrm{COP}_{21}$, which presided the CVF negotiation block of 43 countries and spearheaded the $1.5^{\circ} \mathrm{C}$ negotiation effort, acknowledged that "The GCCM petition played a very critical role in the campaign to raise the ambition in Paris".

3. Over 40,0oo of GCCM members joined the historic Global Climate March

The recent Global Climate March of November 29 (the day before COP21) was the largest climate mobilization in history. GCCM helped mobilize over 40,0oo Catholics to join the massive crowds of 800 ,ooo people in 2,300 rallies in 175 countries.

4. Pope Francis endorsed GCCM and made a powerful call to action

It started in May, when Pope Francis met GCCM and endorsed our campaign, inviting us to increase our efforts to raise awareness among our Catholic family about the moral implications of the climate crisis. A month later, on June 18, the Holy Father released the groundbreaking encyclical Laudato si', 
the first one ever to be devoted entirely to the ecological issue. It issued a powerful message on our moral responsibility to "hear both the cry of the earth and the cry of the poor" that will guide the Church for generations to come. A month after that, on July 10, Pope Francis delivered a powerful speech in Bolivia with a dramatic call to action to defend our common home. And finally, on Nov 29, Pope Francis joined the Global Climate March by sending his shoes to join the thousands of shoes displayed in the Paris march (after the French government prohibition given the terrorist attacks). We were humbled to help facilitate the delivery of the Pope's shoes via Cardinal Hummes.

5. Bishops and Cardinals from all continents supported our mobilization

GCCM mission is blessed to count with the endorsement of many Bishops and Cardinals from all continents, who also issued the remarkable COP21 Bishops' Appeal which urged to "put an end to the fossil fuel era" and "set a goal for complete decarbonization by 2050 ".

\section{6}

1. Paris agreement signature ceremony

Coinciding with this historical event, which happened on Earth Day (April 22), GCCM sent a strong call to action to world leaders gathered in the U.N. headquarters through two initiatives:

- Laudato si' message from the North Pole. On Earth Day, at exactly the same time than the U.N. ceremony, an expedition of Argentinian explorers arrived to the geographical North Pole carrying a copy of Laudato si' and a Global Catholic Climate Movement banner calling on world leaders to "protect our climate \& our common home". Pope Francis sent a letter to the expedition saying: "Thank you for bringing the Laudato si' cry to the polar ice for future generations."

- Interfaith Climate Change Statement. In parallel, GCCM and other faith groups delivered the Interfaith
Climate Change Statement to the President of the UN General Assembly, Mogens Lykketoft. The statement, signed by over 270 high-level religious leaders (including prominent Catholics such as Cardinal Tagle and Bishop Sorondo; plus other renowned faith leaders such as the Dalai Lama and Desmond Tutu) urges governments to ratify and implement the Paris Agreement just days ahead of the official Signing Ceremony at the UN.

\section{Laudato si' week}

GCCM celebrated the encyclical's anniversary (June 18) with a creative offline+online format to raise awareness about the Laudato si' message. Its network hosted over 300 Laudato si' Week events worldwide (including the launch of GCCMPilipinas, pictured below, which represents the first national GCCM network), plus an innovative Laudato si' Online Conference with high-level speakers.

\section{Laudato si' in world youth day}

The GCCM team traveled to Krakow to promote Laudato si' among World Youth Day participants:

- 3 million watched Pope Video premiere. GCCM showcased the "Pope's Creation-Care Video" to 3 million WYD pilgrims in Krakow. This was the only moment in the whole WYD week when Laudato si' was mentioned, and it featured Pope Francis speaking to camera about the importance of caring for our common home, while promoting the Season of Creation website.

- Laudato si' Eco-Village. GCCM convened a Laudato si' Eco-Village in Krakow with multiple events to promote the encyclical message, ranging from a Laudato si' Concert to a Laudato si' Youth Animators training workshop.

\section{Season of Creation}

GCCM led an unprecedented joint Season of Creation campaign together with the World Council of Churches, the Pope's 
Worldwide Prayer Network and other ecumenical institutions, supporting the celebration of hundreds of local events while hosting weekly Laudato si' online prayer sessions.

5. Fossil fuel divestment announcements

GCCM facilitated the first-ever joint Catholic Divestment announcements in June and October 2016, generating large media coverage in Catholic and secular outlets (over 80 hits). This was complemented by the creation of new resources such as a public webinar about the moral case for divestment and a Catholic Divestment Toolkit with GreenFaith.

\section{Other global campaigns}

On one hand, GCCM spearheaded Catholic participation in the Break Free from Fossil Fuels mobilization which was the largest global effort of the climate movement in 2016; the Catholic highlight was the anti-coal march of 10,00o Filipinos led by Archbishop Ramon Arguelles in Lipa, Philippines. On the other hand, in communion with the global Church, GCCM marked major liturgical moments by hosting online campaigns to link climate justice with our Catholic faith: the "Lenten Fast for Climate Justice" and the "Laudato si' -ify your Advent" campaign.

7. Vatican seminar "Laudato si' \& COP22"

GCCM was invited to the "Laudato si" \& $\mathrm{COP}_{22}$ " seminar with Pope Francis in the Pontifical Academy of Sciences. This high-level gathering, convened by Cardinal Turkson and Bishop Sánchez Sorondo, was a great opportunity for GCCM to prepare for $\mathrm{COP}_{22}$ while sharing with the Holy Father the latest updates of our ministry.

8. New grassroots programs

To empower the grassroots, pilots were launched for the following programs: 1) the Laudato si' Animators pilot trained over 500 individuals in both English and Spanish to engage their local communities in Laudato si' Week and the Season of Creation; 2) the Eco-Parish program had a soft launch through the release of the Eco-Parish
Guide and the registration process for an upcoming Eco-Parish Network.

9. $\mathrm{COP}_{22}$ at Marrakech

GCCM Executive Director, Tomás Insua, brought a Catholic voice to the U.N. climate negotiations through speaking engagements as the $\mathrm{COP}_{22}$ Interfaith Statement event, the \#Earth2Marrakech interfaith panel, and GCCM's own "Live from Marrakesh" webinar.

\section{Laudato si' roadshow}

GCCM partnered with the Brazilian Bishops Conference (CNBB) to launch a national Laudato si' roadshow that will visit the country's major dioceses with an educational exhibition to be complemented by Laudato si' talks and distribution of educational materials. Similar partnerships will be pursued with other bishops conferences.

\section{7}

1. Launching the Live Laudato si' Campaign

To celebrate the second anniversary of Pope Francis' groundbreaking encyclical on ecology, Laudato si', GCCM launched the Live Laudato si' campaign. The campaign is a three-year effort to engage 1 million people and institutions in transforming their hearts, improving their lifestyles, and advocating for creation. The centerpiece of the campaign is the Laudato si' Pledge, which has been warmly embraced by the Church. Pope Francis himself encouraged the faithful to sign the pledge. At its official unveiling in Manila, the pledge was endorsed by Cardinal Tagle (watch his great video message), who is the archbishop of Manila and president of Caritas Internationalis, and by scores of Church leaders, helping it spread to six continents.

2. Invigorating the Season of Creation

GCCM successfully coordinated the biggest and most visible Season of Creation to date, in collaboration with its ecumenical partners. Over 500 events on six continents engaged more than 20,000 people in prayers and actions to protect our common home. From a nun-led prayer service at a clean 
energy facility in the heart of coal country in the United States to a pastor-led street cleanup in a village in Uganda, Christians demonstrated that creation care has an important place in the practice of our faith Webinars with Bill McKibben, Fr. Richard Rohr, and global faith leaders touched the hearts of the faithful. More than 70 news articles around the world shared the word with the wider community. The Season of Creation reveals the power of a united Church, and it is quickly becoming a regular and much-anticipated event in parochial calendars.

3. Facilitating Massive Divestment from the Fossil Fuel Industry

GCCM facilitated two history-making announcements of divestment from fossil fuels. A total of 49 Catholic institutions worldwide announced that they were stepping away from dirty energy. This group included the first-ever divestment by a Catholic bishops' conference, one of the first divestments by a Catholic bank and divestment by the major institutions of Assisi. To date, more than 200 articles about these historic Catholic divestments have been published (ranging from CNN, Reuters and Le Monde to Catholic News Service to Breitbart). A single article in the Guardian was shared over $85 \mathrm{k}$ times on social media, including by high-profile figures with audiences in the millions, such as Bill McKibben, Bernie Sanders, Mark Ruffalo, and a host of European policy-makers. This outcome was possible because of an intense outreach effort, which included a high-level "Laudato si' Investing" conference, talks for religious orders, and webinars. The Catholic divestment hub provides helpful information for financial officers and decision-makers, including the first-ever Catholic divestment toolkit, produced as a collaboration between GCCM and Trocaire.

4. Standing up to Harmful Climate Policies in the United States

Standing up to policies that hurt creation and our vulnerable sisters and brothers is important. GCCM collaborated in several milestone activities. In collaboration with FAN and other US partners, we mobilized a sizable and colorful Catholic contingent at the People's Climate March, and followed this by collecting signatures on a petition to President Trump. As the situation in the U.S. worsened, GCCM sounded a strong moral voice for creation. We called on the president to \#ReadLaudatoSi via his favorite medium, Twitter. After Trump announced an intended withdrawal from the Paris climate agreement, we released a statement and coordinated a video interview in front of Trump Tower between Fr. James Martin of America Magazine and Cardinal Ribat. GCCM responded rapidly as developments of US President Donald Trump's withdrawal from the Paris Climate Agreement emerged. 5. Lifting our Voice for Climate Justice

GCCM brought Catholic teaching about justice to public witness on climate change. Executive Director Tomás Insua joined Christiana Figueres and other leaders in cosigning an important article in Nature calling on G2o leaders to take bold action ahead of the 2020 climate turning point. Because media work is critical to the worldwide conversation on climate, we also facilitated the publication of more than 350 news articles and 6 high-profile op-eds. Outside the media sphere, GCCM played a central role in facilitating Catholic leadership for the Paris climate pact by coordinating and speaking at Catholic events at the $\mathrm{COP}_{23}$ summit, representing Catholic voices in the Interfaith $\mathrm{COP}_{23}$ Climate Statement, and working as the lead Catholic partner for a new Interfaith Initiative on Sustainable Lifestyles coordinated by GreenFaith. Our collaborative efforts leveraged the power of united voices: GCCM supported efforts to call for an immediate shift to renewable energy, such as the Big Shift campaign advocating change in World Bank investments and the Lofoten Declaration calling for no new exploitation of fossil fuels. We also joined an amicus brief for Our Children's Trust, the high-profile lawsuit from a group of 20 U.S. children 
to the U.S. federal government based on its harmful climate policies, and we signed a Charter of Values and Actions delivered by Bishop Zuppi to the G7 Ministers of the Environment gathered in Italy.

\section{Celebrating \#Mercy2Earth Weekend}

In 2017, Earth Day immediately preceded Mercy Sunday, the day declared by Pope Francis as a celebration of God's mercy and our own capacity for love. To further Pope Francis' prayer that we "convey mercy throughout our common home," GCCM organized more than 200 events around the world that engaged thousands of people. From planting 3,ooo trees in Pakistan to touching 8,000 worshippers in Nigeria to enacting 40 days of mercy to Earth in Taiwan, Catholic people embodied the heart of Pope Francis' vision.

7. Training Laudato si' Animators Across Continents

Local conversations make the abstract issue of climate change tangible. In 2017 we trained 460 Laudato si' Animators from 60 countries to bring change to their communities. Animators learned the science of climate change, the Laudato si' message, and grassroots organizing, using an online platform to facilitate discussions and quizzes on the material. From our training group, nearly half went on to complete the capstone project hosting an event in their parishes or communities. Others have scheduled events for the spring, or begun the process of starting a green team in their home parish or a chapter in their town. We also translated our Eco-Parish Guide into new languages to help steer parishes' sustainability projects. The events hosted by the Animators reached over 27,00o people, and Animators are now empowered to continue advancing Laudato $s i$ action at a local level across continents.

8. Sharing Laudato si' with the World

Sharing the Laudato si' message with the Catholic family is a big priority for GCCM. To empower robust local efforts on Laudato $s i$, we increased the size and strength of our network, growing the number of member organizations to 650 and sharing the Laudato si' newsletter. Complementing in-depth work on the local level, we facilitated massive awareness campaigns. During the Luján Pilgrimage in Argentina, approximately 1.5 million pilgrims passed through a Laudato si' Station. During Pope Francis' trip to Colombia, 23,00o environmental pilgrim's guides were distributed in the Pope's mass with young people. Also, we thank VIDERE design, CAR Regional Autonomous Corporation, Secretary of the Environment of Bogota SDA (Segretaria Distrital de Ambiente, District Environmental Secretary) for their contribution and the authorization of the Archdiocese of Bogota. GCCM partnered with all of the Rome-based Pontifical Universities to produce a joint diploma on Laudato si', with GCCM staff leading parts of the program, in what promises to be transformative initiative that could be expanded to Catholic universities around the globe.

9. Praying with Laudato si'

GCCM is rooted in the Holy Spirit. Helping the faithful reflect and pray is core to our work. For Lent, we coordinated a worldwide fast for climate on World Water Day. For All Saints and All Souls we created a beautiful prayer resource to honor ecomartyrs and lost species. For $\mathrm{COP}_{23} \mathrm{UN}$ Climate Summit the next stage in the Paris climate talks, we collected prayers from the front lines of climate change, one for each day of the talks. For Advent, we developed a comprehensive resource kit to reflect on and act for creation during the season.

10. Strengthening the Foundations

This was a critical year to consolidate the growth of our young movement. We opened the year with a very fruitful and important Strategic Planning meeting in Assisi, in which our Steering Committee, Board of Directors and Secretariat came together in Assisi to revisit our mission and define our 2017-2020 Strategic Plan. The icing on the cake was our meeting with Pope Francis! And throughout the year we continued to strengthen GCCM's capacity 
by incorporating as a standalone legal entity (after the very generous fiscal sponsorship support from Franciscan Action Network) while expanding our international secretariat from 4 staff in January to 10 staff in December.

\section{8}

1.Church leaders call for urgent change

In June, Pope Francis had two strong speeches targeting the fossil fuel industry, first warning oil CEOs that "energy use must not destroy civilization!", and then a strong criticism of "the thirst for profit that surreptitiously exploits oil and gas fields without regard for our common home". In July, the Vatican convened a high-level conference to celebrate the third anniversary of Laudato si', where Pope Francis called for "systematic and concerted efforts aimed at an integral ecology". In October, the heads of six continental bishops' conferences issued a rare joint statement calling for urgent and ambitious action on climate change to "put an end the fossil fuel era".

2. Christians embrace the Season of Creation

The Season of Creation, a worldwide celebration of prayer and action to protect our common home, was embraced more deeply than ever in 2018. Top faith leaders, including the Vatican's Cardinal Peter Turkson, the Archbishop of Canterbury, Ecumenical Patriarch Bartholomew, and more, signed a groundbreaking statement of support for the season. A high-level prayer service in Assisi, city of St. Francis, brought leaders together. Worldwide, Christians celebrated more than 650 events, an increase of $35 \%$ over last year, and events were held for the first time in the Caribbean, the Middle East, and Oceania.

\section{Polish Catholics care for creation}

Poland, which is more than 90\% Catholic, is the site of some of the worst air pollution in Europe and was the host of this year's UN climate conference, $\mathrm{COP}_{24}$. In the run-up to the climate summit, the bishops of Poland asked the pastors of all 10,000 parishes in the country to pray for the talks-and followed up their invitation with the mailing of 2 million prayer cards to be used during mass. This action followed a year-long series of events: a top-level conference with Cardinal Dziwisz, close friend of St. Pope John Paul II, a visit by the COP 24 president and the Minister of Entrepreneurship and Technology to the Vatican conference on Laudato si, and St. Francis Sunday events with the Minister of Agriculture, bishops, and Catholic supporters around the country. These events were covered in news stories, reaching millions of Polish people.

4. Pilgrims lift their voices for climate justice

Pilgrims on The Climate Pilgrimage walked 1,50o kilometers from St. Peter's Square to the UN climate summit in Katowice, Poland to call for climate justice. Led by former Filipino climate negotiator Yeb Saño, the pilgrims included survivors of Typhoon Haiyan, a storm linked to climate change that killed thousands of people. The pilgrims shared their stories in dozens of communities along their route, and were welcomed by UN climate chief Patricia Espinosa, Austrian President, Italian Environment minister Sergio Costa, and more. Their stories were covered widely in the press and on social media.

\section{Catholics lead at $\mathrm{COP}_{24}$}

The UN climate negotiations, also known as $\mathrm{COP}_{24}$, were a crucial test of the international community's ability to work together for the good of our common home. Even if the summit's outcomes were not as ambitious as it was needed, Catholic voices were prominent at the talks. At the summit, the head of the Holy See delegation held a strong press conference calling for urgency and solidarity, while CIDSE (Coopération Internationale pour le Développement et la Solidarité) and Caritas Internationalis followed the details of the negotiations. On the sidelines, the Pontifical Academy of Sciences convened an all-day conference on climate science, the international Catholic community shared stories of witness and commitment to change, and regional Catholic activists united in reflection. 
6. Church institutions step away from fossil fuels

Catholic institutions continued their prophetic leadership in the movement to divest from fossil fuels. More than 50 Catholic institutions, including Caritas Internationalis and Catholic banks with more than $€ 7.5$ billion on their balance books, stepped away from dirty energy. Caritas India, which was on the front lines of the floods in Kerala that displaced more than a million people, said that "our mission is to bring the gospel's love and compassion to people who need it, and to do that we must step away from the fossil fuels that cause so much suffering". This story was covered widely in the press and in a video seen by hundreds of thousands of people.

7. Care for Creation Enriches the World Meeting of Families

The World Meeting of Families, an international gathering with the Pope held every three years, had a new focus on Laudato si' thanks to a partnership between WMOF (World Meeting of Families), the Laudato si' Working Group of the Irish Council for Catechetics, Trócaire, and GCCM. With a dedicated section on the official website, a video preparing pilgrims to travel sustainably, a meditation garden, a prayer space, activities for teens, and more, this high-profile event reached new audiences with the Laudato si' message.

8. The Catholic community celebrates Earth Day

More than 700 events on six continents, Catholic communities came together for Earth Day. Communities prayed and learned together and encouraged diocesan leaders to commit to protecting creation.

\section{GCCM continues to grow}

Around the world, GCCM continued to grow with committed Catholics taking action in the grassroots. From being trained as a Laudato si' Animator to participating in a Laudato si' Retreat or joining a Laudato si' Circle, the Catholic grassroots found new ways to bring Laudato si' to life. At the same time, GCCM member organizations have continued to lead the charge for climate justice in their regions, ranging from the US based Catholics Are Still In Declaration to Caritas agencies deploying renewable energy to Catholic sisters joining forces to care for our common home.

10. Liturgical resources bring care for creation into our shared life of prayer

With beautiful, comprehensive resources for Lent, Advent, and All Saints and All Souls Days, Catholic people and parishes connected the heart of our faith with care for our common home.

The Global Catholic Climate Movement is grateful to work with a worldwide network of Catholic people and institutions to bring Laudato si' to life. As the needs of our most vulnerable sisters and brothers continue to grow, and in light of the recent IPCC report on reducing greenhouse gas emissions by nearly $50 \%$ in the next 12 years to keep global warming to 1.5 degrees, we are committed to increasing the ambition and urgency of our work in 2019.

\section{Bibliography}

(Web-01) Chazournes de L.B., 2008, United Nations Framework Convention on Climate Change, $<$ http://legal.un.org/avl/pdf/ha/ccc/ccc_e.pdf >, accessed: 14.11.2019.

(Web-02) Union of Concerned Scientists, Climate Impacts, <https://www.ucsusa.org/climate/ impacts $>$, accessed: 14.11.2019.

(Web-03) WHO, 2018, Climate change and health, <https://www.who.int/news-room/fact-sheets/ detail/climate-change-and-health $>$, accessed: 14.11.2019. 


\section{Ekologiczne inicjatywy Global Catholic Climate Movement}

\section{Streszczenie}

Niniejsza publikacja przedstawia strukturę i główne założenia Światowego Ruchu Katolików na Rzecz Środowiska (GCCM) - międzynarodowej organizacji promującej wartości ekologiczne wśród katolików na całym świecie. Opracowanie wskazuje na ścisły związek między nauczaniem Kościoła katolickiego a troską o stworzenie. Wysiłki, mające na celu zapobieganie skutkom zmian klimatu, są wskazywane jako ważna misja dla wierzących, zgodnie z encykliką papieża Franciszka Laudato si'. Istnieją trzy główne wymiary opisujące, jak wprowadzić nauczanie Papieża w życie: wymiar duchowy, wymiar stylu życia i wymiar polityki publicznej. W artykule można znaleźć wiele przykładów dobrych praktyk, które są realizowane od czasu utworzenia GCCM w 2015 r. Po głównej treści następuje szczegółowe kalendarium, prezentujące kluczowe osiągnięcia GCCM.

\section{Słowa kluczowe}

kryzys ekologiczny, chrześcijaństwo, Światowy Ruch Katolików na rzecz Ochrony Środowiska

\section{Nota 0 autorze}

CECILIA DALL'Oglio jest koordynatorką Divest-Invest oraz menadżerką europejskich programów w Global Catholic Climate Movement. Wcześniej pracowała przez 22 lata w FOCSIV, gdzie była odpowiedzialna za kampanie na rzecz zrównoważonego stylu życia i sprawiedliwości klimatycznej (lobbing i rzecznictwo) we współpracy z CIDSE i innymi włoskimi stowarzyszeniami katolickimi oraz częścią Komisji Sprawiedliwości i Pokoju Konferencji Biskupa Włoch. Pracuje na tymczasowym przeniesieniu w biurze FOCSIV w Rzymie.

\section{Author's note}

CeCilia Dali'Oglio is a Divest-Invest \& European Programs Coordinator at the Global Catholic Climate Movement. Before that, she served over 22 years in FOCSIV Federazione degli Organismi Cristiani Servizio Internazionale VoIontario (FOCSIV)where she was responsible for campaigns on sustainable lifestyles and climate justice (lobbying and advocacy) in collaboration with CIDSE and others Italian Catholic associations and part of the Justice and Peace Commission of the Italian Bishop Conference. She works on a secondment based in the FOCSIV office in Rome. 